\title{
ЕНДОГЕННА ІНТОКСИКАЦІЯ ЕКСПЕРИМЕНТАЛЬНИХ ТВАРИН ПРИ ПОШКОДЖЕННІ СІМ'ЯНИКІВ КАДМІЮ ХЛОРИДОМ
}

Вступ. Структурні зміни та ендогенну інтоксикацію при пошкодженні сім'яників шкідливими фракторами екзогенного походження вивчено недостатньо.

Мета дослідження - вивчити особливості змін ендогенної інтоксикації при пошкодженні сім'яників кадмію хлоридом.

Методи дослідження. Застосовано біохімічні та морфологічні методи при вивченні сім'яників 30-ти білих щурів, яких поділили на 2 групи. До 1-ї групи входили 15 інтактних тварин, до 2-ї - 15 щурів, яким вводили підшкірно кадмію хлорид у дозі 6 мг/кг протягом 4-х тижнів. Через місяць від початку експерименту здійснювали евтаназію тварин шляхом кровопускання за умов тіопентал-натрієвого наркозу. В сироватці крові щурів визначали вміст молекул середньої маси, концентрацію ТБК-активних продуктів та окисну модифрікацію протеїнів. Із сім'яників виготовляли гістологічні мікропрепарати, які вивчали морфрометрично. Проводили корелячійний аналіз між біохімічними та морфометричними параметрами. Кількісні показники обробляли статистично.

Результати й обговорення. Тривала дія кадмію хлориду на організм призводила до суттєвого зростання в сироватці крові вмісту молекул середньої маси та збільшення концентрації ТБК-активних продуктів на 48,3 \% (р<0,001), окисної модифрікації протеїнів у сироватці крові щурів, що реєструвалася при довжині хвилі 370 нм, - у 7,4 раза (p<0,001), а при довжині хвилі 430 нм - у 7,68 раза ( $p<0,001)$. Діаметр сім'яних канальців при цьому зменшився на 32,6 \% (p<0,001), кількість клітин епітеліосперматогенного шару знизилась на 31,3 \% (p<0,001), клітин Сертолі - на 11,3 \% ( $<<0,001)$, тубуло-інтерстиційний індекс зменшився на 26,8 \% (p<0,001), індекс інтенсивності сперматогенезу - на 38,8 \% ( $p<0,001)$, а товщина стінки сім'яних канальців збільшилася на 23,6 \% (p<0,001), індекс Лейдіга підвищився на 56,1 \% $(p<0,001)$, відносний об'єм пошкоджених сперматогенних епітеліоцитів зріс у 19,6 раза $(p<0,001)$. Між показниками ендогенної інтоксикації та моророметричними параметрами структур сім'яників виявлено сильні, значні позитивні й негативні кореляційні зв'язки, що підтверджувало залежність ступеня ендогенної інтоксикації від вираження і поширеності морфологічних змін.

Висновки. Введення в організм експериментальних тварин кадмію хлориду призводить до виражених пошкоджень сім'яників і суттєвого зростання ендогенної інтоксикації. Між ступенем порушень ендогенної інтоксикації та досліджуваними морфометричними параметрами структур сім'яників встановлено сильні, значні позитивні й негативні корелячійні зв'язки, що підтверджує залежність вираження ендогенної інтоксикації від поширеності морфологічних змін.

КЛЮЧОВІ СлОВА: сім'яники; ендогенна інтоксикація; кадмію хлорид.

ВСТУП. В останні десятиліття спостерігають зростання техногенного навантаження на довкілля, в результаті чого в ньому збільшується кількість хімічних речовин та їх метаболітів, які можуть негативно впливати на органи і системи організму та погіршувати перебіг різних патологій. Особливо шкідливими для живих організмів $€$ важкі метали, до яких належить кадмій. При цьому може уражатися репродуктивна система у чоловіків [1]. Останнім часом показники репродуктивного і сексуального здоров'я чоловіків знижуються в багатьох країнах світу, але в Україні вони мають стрімку вкрай негативну тенденцію (c) М. С. Гнатюк, С. О. Коноваленко, Л. В. Татарчук, 2020.
[2-4]. Сучасні дослідники підкреслюють недооцінку негативного впливу фракторів довкілля на генеративну фрункцію у чоловіків.

Мета дослідження - вивчити особливості змін ендогенної інтоксикації при пошкодженні сім'яників кадмію хлоридом.

МЕТОДИ ДОСЛІДЖЕННЯ. Вивчено особЛИвості ендогенної інтоксикації та морфології сім'яників 30-ти лабораторних статевозрілих білих щурів-самців, яких поділили на 2 групи. До 1-ї групи входили 15 інтактних тварин, до 2-ї-15 щурів, у яких моделювали пошкодження сім'яників кадмію хлоридом, який вводили підшкірно в дозі 
6 мг/кг протягом 4-х тижнів [5]. Через місяць від початку експерименту здійснювали евтаназію тварин шляхом кровопускання за умов тіопентал-натрієвого наркозу.

У сироватці крові експериментальних тварин визначали вміст молекул середньої маси (МСМ) [6], концентрацію ТБК-активних продуктів (ТБК-АП) [7] та окисну модифрікацію протеїнів (ОМП) [8].

Із сім'яників білих щурів вирізали шматочки, які фріксували в $10 \%$ нейтральному розчині формаліну, їх проводили через етилові спирти зростаючої концентрації і поміщали у парафрінові блоки. Мікротомні зрізи товщиною 5-7 мкм після депарафрінізації забарвлювали гематоксилін-еозином, за Ван-Гізон, Маллорі, Вейгертом, толуїдиновим синім [9].

Морфометрично на мікропрепаратах сім'яників визначали діаметр сім'яних канальців (ДСК), товщину їх стінки (ТС), кількість клітин епітеліосперматогенного шару (КЕСШ), кількість клітин Сертолі (КС), тубуло-інтерстиційний індекс (ТII), індекс Лейдіга (IЛ), індекс інтенсивності сперматогенезу (IIC), відносний об'єм пошкоджених сперматогенних епітеліоцитів (ВОПЕп) [2, 10]. Морфометрію досліджуваних структур сім'яників виконували за допомогою світлового мікроскопа Olimpus BX-23 із цифрровою відеокамерою і пакетом прикладних програм "Відеотест 5,0" та "Відео-розмір 5,0".

Проводили кореляційний аналіз між біохімічними та досліджуваними гістостереометричними показниками з визначенням коефріцієнта (r) кореляції. Силу кореляційних зв'язків оцінювали за чотирма ступенями: сильним ( $r=0,7-0,9)$, значним ( $r=0,5-0,7)$, помірним ( $r=0,3-0,5)$, слабким $(r<0,3)[10]$. Дослідження та евтаназію експериментальних тварин виконували 3 дотриманням Загальних етичних принципів експериментів на тваринах, ухвалених на Першому національному конгресі з біоетики (Київ, 2001), і відповідно до Європейської конвенції про захист хребетних тварин, що використовуються для дослідних та інших наукових цілей [11]. Отримані кількісні показники обробляли статистично. Обробку отриманих даних проведено у відділі системних статистичних досліджень Тернопільського націо- нального медичного університету імені І. Я. Горбачевського МОЗ України у програмному пакеті Statsoft STATISTICA. Різницю між порівнюваними величинами визначали за критеріями Манна Уїтні й Стьюдента [12].

РЕЗУЛЬТАТИ Й ОБГОВОРЕННЯ. ПіД час аналізу отриманих біохімічних показників у сироватці крові експериментальних тварин встановлено, що при дії кадмію хлориду на організм вони суттєво змінювалися (табл. 1). Так, вміст МСМ у сироватці крові, що реєструвалися при довжині хвилі 254 нм 3 вираженою статистично достовірною різницею ( $<<0,001)$ у 2-й групі спостережень, зріс у 2,5 раза порівняно з контролем, а при довжині хвилі 280 нм -у 3,8 раза $(p<0,001)$. Відомо, що МСМ є маркерами ендотоксикозу, що пов'язано з некротичними процесами у досліджуваному органі, посиленням катаболічних процесів унаслідок збільшення при цьому надлишкової кількості біологічно активних речовин, десормованих протеїнових метаболітів та інших ендогенних токсинів [6].

При дії на організм кадмію хлориду спостерігали також виражене зростання концентрації ТБК-АП у сироватці крові, їх вміст збільшився на $48,3$ \% ( $<<0,001)$. Відомо, що надмірне накопичення продуктів пероксидного окиснення ліпідів в організмі призводить до пошкодження мембранних ліпідів, ліпопротеїнів і протеїнів, інактивації ензимів, змін структурно-фрункціональної організації мембран та їх проникності [7].

Встановлено також, що процеси ОМП у сироватці крові щурів, які реєструвалися при довжині хвилі 370 нм, під впливом кадмію хлориду статистично достовірно ( $<<0,001)$ зросли в 7,4 раза. Аналогічно змінилися вони при довжині хвилі 430 нм - збільшилися в 7,68 раза $(p<0,001)$.

Гістологічно у тканинах сім'яників спостерігали виражені судинні розлади, набряк строми, осередки дистрофрічно, некробіотично змінених ендотеліоцитів, міоцитів судин, сперматогенних епітеліоцитів, стромальних структур, локальні клітинні інфільтрати, склеротичні процеси, десквамацію та проліферацію ендотеліоцитів. Останнє свідчило про наявність гіпоксії. Відмі-

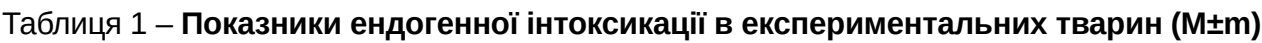

\begin{tabular}{||l|c|c|}
\hline \multirow{2}{*}{\multicolumn{1}{|c|}{ Показник }} & \multicolumn{2}{|c|}{ Група спостереження } \\
\cline { 2 - 3 } & 1-ша & 2-га \\
\hline МСМ, екстинція проб (254 нм) & $0,063 \pm 0,002$ & $0,156 \pm 0,003^{\star \star \star}$ \\
\hline МСМ, екстинція проб (280 нм) & $0,044 \pm 0,003$ & $0,168 \pm 0,006^{\star \star \star}$ \\
\hline ТБК-АП, ммоль·л & $6,58 \pm 0,12$ & $9,76 \pm 0,21^{\star \star \star}$ \\
\hline ОМП, ммоль/г протеїну (370 нм) & $0,610 \pm 0,012$ & $4,520 \pm 0,090^{\star \star \star}$ \\
\hline ОМП, ммоль/г протеїну (430 нм) & $0,250 \pm 0,003$ & $1,920 \pm 0,021^{\star \star \star}$ \\
\hline
\end{tabular}

Примітка. Тут і в таблиці 2: *** - p<0,001. 
чали також осередки набряку ендотеліоцитів судин, просякання їх мембрани протеїнами плазми. У деяких судинах виявляли вогнища фрібриноїдного набухання та некрозу, що вказувало на їх виражене пошкодження. Пошкодження структур сім'яників підтверджували гістостереометричні параметри (табл. 2).

Гістостереометричні показники сім'яників при дії на організм кадмію хлориду істотно змінювалися порівняно з контрольними величинами. Так, діаметр сім'яних канальців 3 високою статистично достовірною різницею $(p<0,001)$ зменшився на 32,6 \%, кількість клітин епітеліосперматогенного шару знизилася на 31,3\% ( $<<0,001)$, клітин Сертолі - на 11,3\% (p<0,001), тубуло-інтерстиційний індекс зменшився на 26,8 \% ( $p<0,001)$, індекс інтенсивності сперматогенезу - на 38,8 \% ( $p<0,001)$.

Товщина стінки сім'яних канальців, індекс Лейдіга, відносний об'єм пошкоджених сперматогенних епітеліоцитів за даних умов експерименту виражено зросли. Так, товщина стінки сім'яних канальців статистично достовірно $(p<0,001)$ збільшилася на 23,6 \% порівняно 3 контрольними параметрами, індекс Лейдіга підвищився на 56,1 \% (р<0,001), відносний об'єм пошкоджених сперматогенних епітеліоцитів зріс у 19,6 раза $(\mathrm{p}<0,001)$.

Під час кореляційного аналізу встановлено наявність сильних позитивних кореляційних зв'язків між ВОПЕп та МСM $(r=+0,81 \pm 0,02)$. Між IIC та МСМ виявлено аналогічної сили негатив-

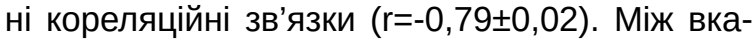
заним моророметричним параметром сім'яників тварин 2-ї групи спостережень і ТБК-АП, ОМП у сироватці крові коесріцієнт кореляції коливався в межах від -0,77 до -0,85 (сильні негативні кореляційні зв'язки). Встановлене свідчить про те, що виражена ендогенна інтоксикація, зумовлена кадмію хлоридом, негативно впливає на сперматогенез [2], тобто призводить до порушення фуункції досліджуваного органа. Між досліджуваними показниками ендогенної інтоксикації та ДСК, КЕСШ, КС, ТІІ виявлено значні негативні кореляційні зв'язки, при цьому коефіцієнт кореляції перебував у межах від -0,59 до -0,66, тобто ендогенна інтоксикація пов'язана також із структурою сім'яників.

Таблиця 2 - Морфометричні показники структур сім'яників експериментальних тварин (M士m)

\begin{tabular}{|c|c|c|}
\hline \multirow{2}{*}{ Показник } & \multicolumn{2}{|c|}{ ГГрупа спостереження } \\
\hline & 1-ша & 2-га \\
\hline ДСК, МКМ & $315,6 \pm 2,7$ & $212,5 \pm 1,8^{\star \star \star}$ \\
\hline TC, мкM & $9,30 \pm 0,06$ & $11,50 \pm 0,07^{\star \star \star}$ \\
\hline КЕСШ & $97,2 \pm 0,9$ & $66,7 \pm 0,6^{\star \star \star}$ \\
\hline $\mathrm{KC}$ & $6,20 \pm 0,05$ & $5,50 \pm 0,03^{\star \star \star}$ \\
\hline TII & $0,560 \pm 0,004$ & $0,410 \pm 0,003^{\star \star \star}$ \\
\hline ІЛ & $8,30 \pm 0,07$ & $12,96 \pm 0,07^{\star \star \star}$ \\
\hline $\mathrm{IIC}$ & $11,60 \pm 0,09$ & $7,10 \pm 0,05^{\star \star \star}$ \\
\hline ВОПЕП, \% & $2,40 \pm 0,03$ & $47,20 \pm 0,39^{\star \star \star}$ \\
\hline
\end{tabular}

ВИСНОВКИ. Введення в організм експериментальних тварин кадмію хлориду призводить до виражених пошкоджень сім'яників і суттєвого зростання ендогенної інтоксикації. Між ступенем порушень ендогенної інтоксикації та досліджуваними морфометричними параметрами структур сім'яників встановлено сильні, значні позитивні й негативні кореляційні зв'язки, що підтвер- джує залежність вираження ендогенної інтоксикації від поширеності морфологічних змін.

Перспективи подальших досліджень. Всебічне дослідження структур сім'яників та ендогенної інтоксикації при пошкодженні їх кадмію хлоридом сприятиме суттєвому розширенню діагностики, корекції і профрілактики цієї патології.

\section{СПИСОК ЛІТЕРАТУРИ}

1. Дубініна А. А. Токсичні речовини і методи їх визначення / А. А. Дубініна. - Харків : ХДУХТ, 2016. $106 \mathrm{c}$.

2. Базалицька С. В. Чоловіча неплідність в Україні: особливості пато- і морфогенезу / С. В. Базалицька. - К. : ТОВ “Четверта хвиля", 2016. - 262 с.

3. Гнатюк М. С. Особливості ремоделювання судин гемомікроциркуляторного русла яєчок при пострезекційній портальній гіпертензії / М. С. Гнатюк,
С. О. Коноваленко, Л. В. Татарчук // Шпитальна хірургія. - 2019. - № 4 (88). - С. 37-41.

4. Долинко Н. П. Влияние гинко билоба на морфометрические и фрункциональные показателя сперматозоидов в условиях хронической этаноловой интоксикации / Н. П. Долинко // Вестнік Могілеускага дзяржаунага універсітэта імя А. А. Куляшова. Серыя Прыроданаучия наукі. - 2015. - № 2 (46). C. 99-102. 
5. Коноваленко С. О. Структурні зміни в яєчку при дії на організм хлориду кадмію / С. О. Коноваленко, В. В. Лотоцький, Л. В. Татарчук // Проблеми військової охорони здоров'я. - 2016. - № 45. - Р. 199-206.

6. Корякина Е. В. Молекулы средней массы как интегральный показатель метаболических нарушений / Е. В. Корякина, С. В. Белова // Клинич. и лаб. диагностика. - 2004. - № 3. - С. 3-8.

7. Стальная И. Д. Метод определения малонового альдегида с помощью тиобарбитуровой кислоты / И. Д. Стальная, Т. Г. Гаришвили // Современные методы в биохимии. - М. : Медицина, 1977. - С. 66-68.

8. Мещишен І. Ф. Метод визначення окислювальної модифрікації білків плазми (сироватки) крові /

\section{REFERENCES}

1. Dubinina, A.A. (2016). Toksychni rechovyny $i$ metody yikh vyznachennia [Toxic substances and methods for their determination]. Kharkiv: KHDUKHT [in Ukrainian].

2. Bazalytska, S.V. (2016). Cholovicha neplidnist v Ukraini: osoblyvosti pato- $i$ morphohenezu [Male infertility in Ukraine: features of pathogenesis and morphogenesis]. Kyiv: TOV "Chetverta khvylia" [in Ukrainian].

3. Hnatyuk, M.S., Konovalenko, S.O., \& Tatarchuk, L.V. (2019). Osoblyvosti remodeliuvannia sudyn hemomikrotsyrkuliatornoho rusla yaiechok pry postrezektsiinii portalnii hipertenzii [Peculiarities of vascular remodeling of hemo-microcirculatory bed of testes at postresection portal hypertension]. Shpytalna khirurhiiaHospital Surgery, 4, 37-42 [in Ukranian].

4. Dolynko, N.P. (2015). Vliyanie ginko biloba na morfometricheskie i funktsionalnye pokazateli spermatozoidov v usloviyakh khronicheskoy etanolovoy intoksikatsii [The influence of ginkgo biloba on the morphometric and functional indicator of spermatozoa in conditions of chronic ethanol intoxication]. Vestnik Mogelevskogo derzhavnogo universytetu im. A.A.Kulyashova. Seriya Pryrodnychi nauky - Bulletin of Mogilev State University by A.A. Kuleshov. Natural Science Series, 2 (46), 99-102 [in Russian].

5. Konovalenko, S.O., Lototskyi, V.V., \& Tatarchuk, L.V. (2016) Strukturni zminy v yaiechku pry dii na orhanism khlorydu kadmiiu [Structural changes in the testis when exposed to cadmium chloride]. Problemy viiskovoi okhorony zdorovia - Problems of Military Health Care, 45, 199-206 [in Ukrainian].

6. Koryakina, Ye.V., \& Belov, S.V. (2004). Molekuly sredney massy kak integralnyy pokazatel metaboli-
І. Ф. Мещишен // Буковин. мед. вісн. - 1998. - № 1. C. $156-158$.

9. Горальський Л. П. Основи гістологічної техніки і морфофрункціональні методи досліджень у нормі та при патології / Л. П. Горальський, В. Т. Хомич, О. І. Кононський. - Житомир : Полісся, 2011. - 288 с.

10. Автандилов Г. Г. Основы количественной патологической анатомии / Г. Г. Автандилов. - М. : Медицина, 2002. - 240 с.

11. Резніков О. Г. Загальні етичні принципи експериментів на тваринах / О. Г. Резніков // Ендокринологія. - 2003. - 8, № 1. - С. 142-145.

12. Лапач С. Н. Статистические методы в медико-биологических исследованиях Excell / С. Н. Лапач, А. В. Губенко, П. Н. Бабич. - К. : Морион, 2001. -410 с.

cheskikh narusheniy [Molecules of the average mass as an integral index of metabolic disturbances]. Klin. $i$ lab. diagnostika - Clinical and Laboratory Diagnostics, 3, 3-8 [in Russian].

7. Stalnaya, I.D., \& Garishvily, T.G. (1977). Metod opredeleniya malonovogo aldegida s pomoshchyu tiobarbiturovoy kisloty [The method of determination of malonic aldehyde with tiobarbituric acid]. Sovremennyye metody $v$ biokhimii - Modern Methods in Biochemistry. Moscow: Meditsina [in Russian].

8. Meshchyken, I.F. (1988). Metod vyznachennia okysliuvalnoi modyfikatsii bilkiv plazmy (syrovatky) krovi [The method of determination of oxidative modification of plasma proteins (serum)]. Bukov. Med. Visnyk - Bukovinian Medical Journal, 1,156-157 [in Ukrainian].

9. Goralsky, L.P., Khomich, V.T., \& Kononsky, O.I. (2011). Osnovy histolohichnoi tekhniky i morfofunktsionalni metody doslidzhen u normi i pry patolohii [Fundamentals of histological technique and morphofunctional methods of research in norm and pathology]. Zhytomyr: Polissia [in Ukrainian].

10. Avtandylov, G.G. (2002). Osnovy kolychestvennoy patologicheskoy anatomii [Basis of quantative pathological anatomy]. Moscow: Meditsyna [in Russian].

11. Reznykov, O.H. (2003). Zahalni etychni pryntsypy eksperymentiv na tvarynakh [General ethical principles experiments on animals]. Endokrynolohiia - Endocrinology,8, 1, 142-145 [in Ukrainian].

12. Lapach, S.N., Gubenko, A.V., \& Babych, P.N. (2001). Statisticheskye metody v miediko-biolohicheskykh issledovanyiakh Excell [Statistical methods in biomedical research Excell]. Kyiv: Morion [in Ukrainian]. 


\title{
ЭНДОГЕННАЯ ИНТОКСИКАЦИЯ ЭКСПЕРИМЕНТАЛЬНЫХ ЖИВОТНЫХ ПРИ ПОВРЕЖДЕНИИ СЕМЕННИКОВ КАДМИЯ ХЛОРИДОМ
}

\begin{abstract}
Резюме
Вступление. Структурные изменения и эндогенная интоксикация при повреждении семенников вредными фракторами экзогенного происхождения изучены недостаточно.

Цель исследования - изучить особенности изменений эндогенной иптоксикации при повреждении семенников кадмия хлоридом.

Методы исследования. Применены биохимические и морфологические методы при изучении семенников 30-ти белых крыс, которых разделили на 2 группы. В 1-ю группу входили 15 интактных животных, во 2-ю - 15 крыс, которым вводили подкожно кадмия хлорид в дозе 6 мг/кг в течение 4-х недель. Через месяц после начала эксперимента осуществляли эвтаназию животных путем кровопускания в условиях тиопентал-натриевого наркоза. В сыворотке крови крыс определяли содержание молекул средней массы, концентрацию ТБК-активных продуктов и окислительную модификацию протеинов. Из семенников изготавливали гистологические микропрепараты, которые изучали морфометрически. Проводили корреляционный анализ между биохимическими и морфометрическими параметрами. Количественные показатели обрабатывали статистически.

Результаты и обсуждение. Длительное воздействие кадмия хлорида на организм приводило к существенному росту в сыворотке крови содержания молекул средней массы и увеличению ТБК-активных продуктов на 48,3 \% (р<0,001), окислительной модификации протеинов в сыворотке крови крыс, что регистрировалась при длине волны 370 нм, - в 7,4 раза $(p<0,001)$, а при длине волны 430 нм - в 7,68 раза ( $<<0,001)$. Диаметр семенных канальцев при этом уменьшился на 32,6 \% (p<0,001), количество клеток эпителиосперматогенного слоя снизилось на 31,3\% (p<0,001), клеток Сертоли - на 11,3 \% (p<0,001), тубуло-интерстициальный индекс уменьшился на 26,8 \% (p<0,001), индекс интенсивности сперматогенеза - на 38,8 \% (p<0,001), а толщина стенки семенных канальцев увеличилась на 23,6 \% (p<0,001), индекс Лейдига повысился на 56,1 \% (p<0,001), относительный объем поврежденных сперматогенных эпителиоцитов вырос в 19,6 раза (p<0,001). Между показателями эндогенной интоксикации и морфометрическими параметрами структур семенников выявлены сильные, значительные положительные и отрицательные корреляционные связи, что подтверждало зависимость степени эндогенной интоксикации от выраженности и распространенности морфологических изменений.

Выводы. Введение в организм экспериментальных животных кадмия хлорида приводит к выраженным повреждениям семенников и существенному росту эндогенной интоксикации. Между степенью нарушений эндогенной интоксикации и исследуемыми морфометрическими параметрами структур семенников установлены сильные, значительные положительные и отрицательные корреляционные связи, подтверждающие зависимость выраженности эндогенной интоксикации от распространенности морфологических изменений.
\end{abstract}

КЛЮЧЕВЫЕ СЛОВА: семенники; эндогенная интоксикация; кадмия хлорид.

M. S. Hnatyuk, S. O. Konovalenko, L. V. Tatarchuk I. HORBACHEVSKY TERNOPIL NATIONAL MEDICAL UNIVERSITY

\section{ENDOGENOUS INTOXICATION OF EXPERIMENTAL ANIMALS AT DAMAGE OF THE TESTES BY CADMIUM CHLORIDE}

Summary

Introduction. It is known that structural changes and endogenous intoxication at damage of the testes by harmful factors of exogenous origin have been insufficiently studied.

The aim of the study - to investigate the features of changes of endogenous intoxication at damage of the testes by cadmium chloride.

Research Methods. Biochemical and morphological methods were used to study the testes of 30 white rats, which were divided into 2 groups. Group 1 consisted of 15 intact animals, group $2-15$ rats, which were injected 
subcutaneously with cadmium chloride at a dose of $6 \mathrm{mg} / \mathrm{kg}$ for 4 weeks. One month after the start of the experiment, euthanasia of experimental animals was performed by bloodletting under conditions of thiopental anesthesia. The content of medium weight molecules, the concentration of TBA-active products and oxidative modification of proteins were determined in the serum of rats. Histological micronutrients were made from the testes and studied morphometrically. Correlation analysis was performed between biochemical and morphometric parameters. Quantitative indicators were processed statistically.

Results and Discussion. Prolonged exposure to cadmium chloride to the body led to a significant increase in serum molecules of medium weight and an increase in TBA-active products by $48.3 \%(p<0.001)$, oxidative modification of proteins in the serum of rats, that was recorded at a wavelength of $370 \mathrm{~nm}-7.4$ times $(p<0.001)$, and when determining their wavelength $430 \mathrm{~nm}-7.68$ times $(p<0.001)$. The diameter of the seminal tubules decreased by $32.6 \%(p<0.001)$, the number of epithelial-spermatogenic layer cells - by $31.3 \%(p<0.001)$, Sertoli cells - by $11.3 \%(p<0.001)$, tubulo-interstitial index - by $26.8 \%(p<0.001)$, the index of spermatogenesis intensity - by $38.8 \%$ $(p<0.001)$, and the wall thickness of the seminal tubules increased by $23.6 \%(p<0.001)$, the Leydig index - by $56.1 \%(p<0.001)$, the relative volume of damaged spermatogenic epitheliocytes -19.6 times $(p<0.001)$. Strong, significant positive and negative correlations were found between the indicators of endogenous intoxication and morphometric parameters of testicular structures, which confirmed the dependence of the degree of endogenous intoxication on the severity and prevalence of morphological changes.

Conclusion. The introduction of cadmium chloride into the body of experimental animals leads to severe damage of the testes and a significant increase in endogenous intoxication. Strong, significant positive and negative correlations have been established between the degree of endogenous intoxication disorders and the studied morphometric parameters of testicular structures, which confirms the dependence of the severity of endogenous intoxication on the prevalence of morphological changes.

KEY WORDS: testes; endogenous intoxication; cadmium chloride.

Адреса для листування: М. С. Гнатюк, Тернопільський національний медичний університет імені І. Я. Горбачевського мО3 України, майдан Волі, 1, Тернопіль, 46001, Україна, e-mail: hnatjuk@tdmu.edu.ua. 